\title{
The sympathetic nervous system in white adipose tissue regulation
}

\author{
D. Vernon Rayner \\ Molecular Physiology Group, Rowett Research Institute, Bucksburn, Aberdeen AB21 9SB, UK
}

\begin{abstract}
Sympathetic stimulation has long been recognized to mobilise fatty acids from white adipose tissue. However, it is now apparent that adipose tissue is not only concerned with energy storage as fat, but is a major endocrine and secretory organ. This change has resulted from the identification of leptin as a hormone of energy balance secreted by white adipose tissue. The sympathetic system is a key regulator of leptin production in white fat. Sympathomimetic amines, cold exposure or fasting (which lead to sympathetic stimulation of white fat), decrease $o b$ gene expression in the tissue and leptin production. On the other hand, sympathetic blockade often increases circulating leptin and $o b$ gene expression, and it is postulated that the sympathetic system has a tonic inhibitory action on leptin synthesis. In rodents this action is through stimulation of $\beta 3$-adrenoceptors. The adrenal medulla (as opposed to the direct sympathetic innervation) has been thought to play only a minor role in the catecholaminergic regulation of white adipose tissue. However, in rodents responses of the leptin system to adrenergic blockade vary with the method used. Changes in leptin and $o b$ gene expression are considerably less using methods of blockade that only effect the terminal adrenergic innervation, rather than medullary secretions as well. Stimulation of the leptin system increases sympathetic activity and hence metabolic activity in many tissues. As well as leptin, other (but not all) secretions from white adipose tissue are subject to sympathetic regulation. In obesity the sympathetic sensitivity of adipose tissue is reduced and this factor may underlie the dysregulation of leptin production and other adipose tissue secretions.
\end{abstract}

\section{Sympathetic nervous system: White adipose tissue: Leptin production:} $\beta$-Adrenoceptors: Obesity

The present short review considers the role of the sympathetic nervous system in the regulation of white adipose tissue (WAT). From the early studies of Cannon (1929) came the concept of the sympathetic nervous system and the adrenal medulla being present to prepare the animal for 'fight or flight' by raising blood glucose, mobilising fatty acids from adipose tissue, increasing heart rate, redistributing blood flow and elevating metabolic rate. Cannon (1929) thought that the adrenal medulla was more important than the sympathetic innervation. However, it has become accepted that as far as the mobilisation of fat is concerned, the direct sympathetic innervation of adipose tissue is more important than the adrenals. Briefly, the evidence can be summarised as being that sympathetic denervation leads to an increase in adipose tissue weight relative to the nondenervated pad; nerve stimulation results in fatty acid release, and sympathetic or ganglionic blockade inhibits the mobilisation of lipid (Gilgen et al. 1962; Rebuffé-Scrive, 1991), while adrenal demedullation is not effective.
Adipose tissue has thus been regarded as an organ for energy storage as fat, with the sympathetic nervous system being the major regulator of fat mobilisation to provide homeostasis of energy supply. Although adipose tissue secretions such as adipsin and tumour necrosis factor $\alpha$ (TNF- $\alpha$ ) predate the discovery of leptin, the cloning of the $o b$ gene (Zhang et al. 1994) and the finding that leptin, the resulting hormone, secreted primarily from WAT, decreased food intake and increased energy expenditure, has shown that adipose tissue is a major endocrine organ. Other protein factors and cytokines from WAT, which act both locally or systemically, have also been identified (Mohamed-Ali et al. 1998). The present brief review will seek to show the importance of the sympathetic nervous system in the regulation of the metabolic and secretory functions of adipose tissue, and will suggest that there is some evidence for the involvement of the adrenal medulla in the responses.

\footnotetext{
Abbreviations: BAT, brown adipose tissue; $6 \mathrm{OHD}, 6$-hydroxydopamine; $\alpha \mathrm{MPT}, \alpha$-methyl- $p$-tyrosine; TNF, tumour necrosis factor; UCP, uncoupling protein; WAT, white adipose tissue.

Corresponding author: Dr Vernon Rayner, fax +44 1224 716686, email dvr@rri.sari.ac.uk
} 


\section{Sympathetic activity in fat relative to other tissues}

Changes in sympathetic activation in individual tissues are often studied by examining the rate of noradrenaline turnover within the tissue. In most tissues a decrease in turnover is associated with fasting (Young \& Lansberg, 1977), while an increase occurs in cold exposure or overfeeding, as energy expenditure increases either to counteract the cold or the excess energy intake. As expected, noradrenaline turnover increases in WAT in cold-exposed rodents (Garofalo et al. 1996), but also in fasted rodents (Migliorini et al. 1997). There is, therefore, elevated (not decreased) sympathetic activity and raised fatty acid mobilisation from WAT in fasting as well as in cold exposure.

These responses are thought to primarily involve the direct sympathetic innervation. This theory is based on the experimental evidence detailed earlier, and also on our understanding of the excitation of adrenergic receptors and the known levels of circulating catecholamines. The $\beta 3$ adrenoceptor is the predominant $\beta$-subtype in adipose tissue of rodents (although not in man) and has a decreased affinity for adrenaline relative to that exhibited by $\beta 1$ - or $\beta 2$ adrenoceptors, and for noradrenaline an affinity less than that of $\beta 1$-adrenoceptors but greater than that of $\beta 2$ adrenoceptors (Tate et al. 1991). The $\beta 3$-receptor is, therefore, more likely to be stimulated by the high noradrenaline concentrations that will be found in the immediate vicinity of the terminal adrenergic nerve fibre (Fig. 1) than by catecholamines derived from the circulation (Giacobino, 1996). Normally, circulating adrenaline levels (derived entirely from the adrenal medulla) are lower (Kopin, 1989) than the level of noradrenaline (derived mainly from sympathetic overspill), and may not be high enough to be physiologically important in comparison with the direct sympathetic innervation. However, circulating adrenaline levels may be raised at times of stress if blood glucose falls (e.g. fasting, cold exposure), and may then contribute to the sympathetic response in adipose tissue (Young et al. 1984). Further indications that adrenaline may be involved will be shown when the effects of different methods of sympathetic blockade are considered. However, circulating adrenaline is likely to be more important in man, due to the decreased sensitivity of human adipose tissue to $\beta 3$-adrenoceptor stimulation (Arch \& Wilson, 1996) and the greater importance of $\beta 2$-receptors, which are more sensitive to adrenaline. Thus, adrenaline and noradrenaline are equally potent in increasing glycerol secretion from adipose tissue in human subjects (Hjemdahl \& Linde, 1983); $\beta 3$-adrenoceptors have been estimated to be only $20 \%$ of the total population of $\beta$-adrenoceptors in human WAT, and although stimulation of $\beta 3$-adrenoceptors can be demonstrated, effects of isoprenaline are mediated exclusively by $\beta 1$ - and $\beta 2$-receptors (Tavernier et al. 1996).

One final consideration is that WAT also contains $\alpha 1-$ and $\alpha 2$-receptors (Lafontan \& Berlan, 1993). The $\alpha 2$ adrenoceptors like $\beta 3$-receptors are G-protein coupled, but decrease rather than increase adenyl cyclase levels. $\alpha 2$ Receptor stimulation may therefore be expected to have the reverse effects to $\beta 3$-receptor stimulation. For lipolysis, stimulation of $\alpha 2$ - and $\beta 3$-receptors have been suggested to

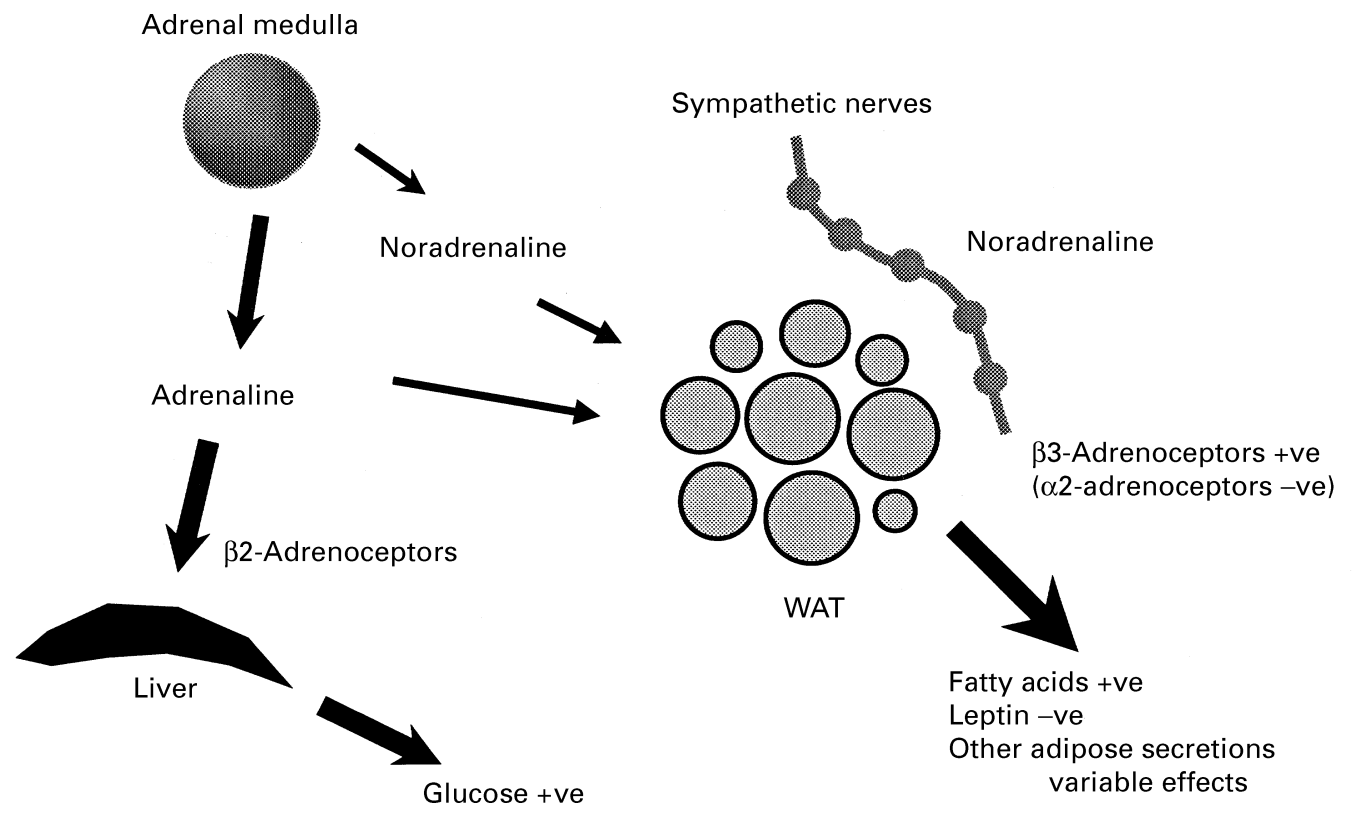

Fig. 1. Sympathetic regulation of white adipose tissue (WAT): Sympathetic regulation is provided by high concentrations of noradrenaline released from sympathetic nerves and stimulating $\beta 3$-adrenoceptors (also inhibitory $\alpha 2$-receptors) in rodent WAT. Stimulation of $\beta 3$-adrenoceptors leads to the mobilisation of fatty acids, as an energy source for other tissues, but inhibits the secretion of the hormone leptin, and has variable effects on a number of tissue factors and cytokines. The adrenal medulla secretes mainly adrenaline into the circulation, an important function of which is to raise blood glucose by stimulating liver $\beta 2$-receptors. Circulating adrenaline levels are often not high enough to affect WAT $\beta 3$-receptors, but sufficient adrenaline may be secreted when stimulated by a fall in plasma glucose, particularly in man where $\beta 2$-adrenoceptors are more important in adipose tissue. +ve, stimulation; -ve, inhibition. 
have an interplay, with $\alpha 2$-receptors predominating and decreasing lipolysis at low concentrations of catecholamines, while $\beta 3$-receptors are more important at higher

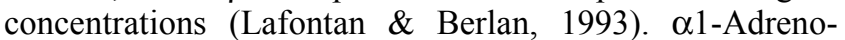
ceptors are less abundant and may not be involved in lipolysis, but their stimulation increases glycolysis, and hence lactate production (Faintrenie \& Geloen, 1996). There are differences in receptor sensitivity between depots and with obesity in man. Thus, omental fat in obese human subjects has increased $\beta 3$-receptor and decreased $\alpha 2$ receptor effects on lipolysis compared with subcutaneous fat (Richelsen et al. 1991; Hoffstedt et al. 1997). The possible interplay of $\alpha$ - and $\beta$-adrenoceptor effects and differences between depots in relation to obesity merits further consideration in relation to the sympathetic regulation of leptin, and other adipose tissue secretions as well.

\section{Short-term regulation of leptin production}

Although $o b$ gene expression in WAT and leptin levels are related to adiposity, leptin as well as some other adipose tissue secretions are subject to short-term regulation. The present review will aim to show that the sympathetic system is a key regulatory system. Other factors that regulate leptin production have been reviewed by Trayhurn \& Beattie (2001). Acute treatment with catecholamines in both experimental animal and human studies reduce circulating leptin. This process occurs via $\beta 3$-adrenoceptors in rodents, as selective $\beta 3$ agonists (BRL 35153A, CL31643 etc.) suppress leptin gene expression and decrease leptin levels (Moinat et al. 1995; Trayhurn et al. 1996). In human subjects, although there is some evidence that $\beta 3$-receptors may be involved in fatty acid mobilisation from WAT (Enocksson et al. 1995), the sympathetic regulation of WAT is likely to be mainly through $\beta 1$ - and $\beta 2$-receptors (Sennitt et al. 1998). Second, fasting leads to a rapid profound fall in $o b$ gene expression, which is rapidly reversible and therefore not related to any change in body adiposity, in both experimental animal and human studies (Trayhurn et al. 1995b; Boden et al. 1996). Third, cold exposure leads to increased noradrenaline turnover and hence sympathetic stimulation, an increased metabolic rate and mobilisation of fatty acids in order to maintain body temperature and a rapid decrease in leptin gene expression and plasma leptin levels (Trayhurn et al. 1995a; Bing et al. 1997), and are rapidly reversed on rewarming; again indicating a key role for leptin in nutritional regulation rather than reflecting changes in adiposity.

Another way of elucidating the importance of the sympathetic nervous system in leptin production is by the use of adrenergic blockade and is considered in detail elsewhere. Briefly, sympathetic blockade can give evidence of the tonic regulation of leptin production (Trayhurn \& Beattie, 2001), but studies have been limited by the lack of effective $\beta 3$-adrenoceptor blockers. Sympathetic blockade can be achieved by using $\alpha$-methyl- $p$-tyrosine ( $\alpha \mathrm{MPT}$ ), an inhibitor of tyrosine hydroxylase, to inhibit catecholamine synthesis (Young \& Lansberg, 1977) in peripheral sympathetic nerves and in the adrenal medulla. The action of $\alpha M P T$ will be considered in some detail because of the contrast in the extent of its effects compared with those of 6-hydroxydopamine (6OHD). Administration of $\alpha \mathrm{MPT}$ provides an effective block of all sympathetic effects and leads to an increase in leptin level of up to 8-fold within $8-10 \mathrm{~h}$ in lean mice; $\alpha \mathrm{MPT}$ more than reversed the fall in leptin level and $o b$ mRNA in response to a $24 \mathrm{~h}$ fast (Rayner et al. 1998). These effects must be contrasted with those of 6OHD, which chemically sympathectomises the peripheral sympathetic innervation without affecting brain adrenergic systems or the adrenal medulla. During fasting 6OHD raises leptin levels, but to a lesser extent than $\alpha \mathrm{MPT}$ (Sivitz et al. 1999). Levels of $o b$ gene mRNA increased in brown adipose tissue (BAT) in this study, although not in WAT, suggesting that the change in leptin in response to 6OHD may represent an increased output from BAT. In recent experiments we have been unable to increase leptin levels or $o b$ gene expression in WAT in fasted mice by sympathetic blockade with 6OHD. In these mice fasting surprisingly raised plasma noradrenaline levels up to 4 -fold. This rise was inhibited by 6OHD, suggesting effective sympathetic neurone blockade. The differential effects of $6 \mathrm{OHD}$ relative to $\alpha \mathrm{MPT}$ may relate to continued adrenaline secretion. However, despite the profound effects of some forms of sympathetic blockade, sympathetic knockout mice (unable to synthesise dopamine $\beta$-hydroxylase; Thomas \& Palmiter, 1997) are surprisingly non-obese, with a raised metabolic rate. Uncoupling protein (UCP) 1 but not UCP2 mRNA levels are raised but, as expected, animals are cold intolerant. Understanding sympathetic regulation of WAT and its relationships with other regulatory systems still has some way to go.

\section{Sympathetic innervation}

Although sympathetic nerve fibres are known to follow the blood vessels to WAT, a key question has been whether there is direct sympathetic innervation of the white adipocytes, rather than transmitter spillover from the sympathetic innervation of the blood supply (Bartness \& Bamshad, 1998 ) or sympathetic changes in tissue permeability. Nerve fibres in close apposition with adipocytes (Cinti, 1999) have been demonstrated and is comprehensively covered in another review from the present symposium (Cinti, 2001). Functional sympathetic nerves regulating lipolysis have also been shown (Gilgen et al. 1962; Rebuffé-Scrive, 1991). The sympathetic pathways involved have been identified by retrograde tracing of pseudorabies virus, injected into inguinal and epididymal WAT pads in hamsters and rats. The sympathetic pathway was traced back through the intermediolateral cell group to the central autonomic nucleus of the spinal cord; in the brain stem pseudorabies virus-labelled cells were seen in a number of areas, including the solitary tract, which is known to be involved in the control of voluntary food intake (and which contains leptin receptors; Mercer et al. 1998). In the hypothalamus prominent pseudorabies virus labelling was seen in the paraventricular nucleus, which is known to be involved in sympathetic responses (e.g. paraventricular nucleus stimulation induces sympathetically-mediated lipolysis; Bartness \& Bamshad, 1998). However, little labelling was evident in the ventromedial hypothalamus, even though this region has long been associated with sympathetic effects (e.g. leptin injection into ventromedial hypothalamus (Satoh et al. 
1999) leads to an increase in circulating catecholamines). Finally, sympathetic connections are also seen in the suprachiasmatic nucleus, which is known to be concerned with the initiation and regulation of circadian rhythms, and may relate to the circadian variation in leptin levels. Clearly, there is a functional sympathetic innervation from the areas of the brain that are involved in the regulation of energy balance. Finally, there is evidence of leptin-sensitive afferent pathways from sympathetic tissues (Niijima, 1998), and the importance of afferent sympathetic pathways from adipose tissue will need to be evaluated.

\section{The sympathetics and energy expenditure in white adipose tissue compared with other tissues}

As well as decreasing food intake, leptin increases energy expenditure (Campfield et al. 1995; Pellymounter et al. 1995) through the sympathetic system. The evidence for sympathetic feedback to adipose tissue following leptin secretion will be considered (Fig. 2). Leptin (intracerebroventricular or into the ventromedial hypothalamus) has been shown to increase circulating adrenaline and noradrenaline levels (i.e. stimulate both sympathetic nerves and the adrenal medulla; Satoh et al. 1999), although another report has suggested that this increase is primarily brought about by an increase in sympathetic nerve activity (Haque et al. 1999). In rodents these effects on energy expenditure involve the sympathetic stimulation of UCP1 activity in BAT (Scarpace et al. 1997) and are prevented by sympathetic denervation of BAT (Scarpace \& Matheny, 1998). Leptin has been shown to increase noradrenaline turnover in BAT (Collins et al. 1996); it increases sympathetic nerve activity to the kidney, adrenals and the hindlimb (Dunbar

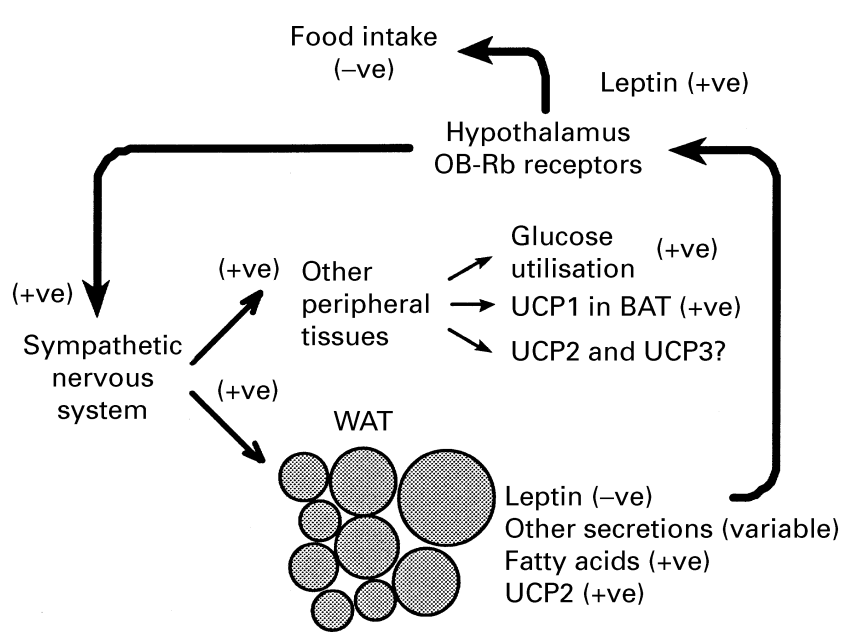

Fig. 2. Negative feedback to white adipose tissue (WAT) through the sympathetic nervous system: Leptin stimulates the hypothalamic OB-Rb splice variant of the leptin receptors to decrease food intake and increase sympathetic activity, principally through sympathetic nerves and their transmitter noradrenaline. Sympathetic stimulation increases glucose utilization, increases heat production through uncoupling protein (UCP) 1 in brown adipose tissue (BAT) and possibly through UCP2 and 3 in other tissues (e.g. muscle and WAT). Sympathetic stimulation provides negative feedback to WAT to limit leptin production. +ve, stimulation; -ve, inhibition. et al. 1997; Haynes et al. 1997) and glucose uptake in heart, BAT and striated muscle (Minokoshi et al. 1999), but not in WAT. Leptin has also been shown to increase glucose turnover in the liver and decrease hepatic glycogen content (Kamora et al. 1997), suggesting the involvement of adrenaline in the responses. Although sympathetic effects following leptin administration have been demonstrated in many tissues, there has been less evidence of a closed feedback loop changing energy metabolism in WAT. Leptin does increase UCP2 and UCP3 gene expression in this tissue (Zhou et al. 1997; Liu et al. 1998; Scarpace et al. 1998). However, sympathetic stimulation of WAT has yielded varying effects on UCP gene expression in WAT. $\beta 3$ Adrenoceptor agonists increased UCP2 and UCP3 mRNA in the rat (Emilsson et al. 1998), although other groups have reported no change in UCP2 and UCP3 gene expression (Savontaus et al. 1998; Gomez-Ambrosi et al. 1999). Sympathetic stimulation by cold exposure $(16 \mathrm{~h})$ did not change UCP2 mRNA in WAT in the rat (Fleury et al. 1997), although this period of cold exposure may have been insufficient. Fasting increases UCP2 and UCP3 mRNA in WAT (although UCP3 gene expression is low in WAT) in both mouse and rat (Boss et al. 1997, 1998; Ricquier \& Bouillaud, 2000). This effect may be unrelated to the sympathetic stimulation, as consistently mRNA levels for UCP2 and UCP3 in WAT and muscle are increased at times of increased fatty acid metabolism (high-fat diets, obesity, fasting), suggesting that these UCP may have a role in the regulation of fatty acid metabolism (Boss et al. 1998). In summary, although leptin alters UCP2 and UCP3 gene expression, the role of UCP2 and UCP3 in the sympathetic stimulation of energy metabolism in WAT through UCP is not completely established.

\section{Cyclic nature of leptin production}

Leptin levels do not increase immediately with feeding in the manner that many other hormones do. Overfeeding has been shown to raise leptin levels (Kolaczynski et al. 1996). This effect is unlikely to be related to the increased sympathetic activity induced by overfeeding (Lansberg \& Young, 1978), which may be expected to decrease circulating leptin. In man and rodents leptin levels peak at night and fall to a nadir the next morning (Sinha et al. 1996; Licinio et al. 1997). Much of this diurnal pattern is entrained to the meal pattern (Schoeller et al. 1997) and peaks before the maxima in the adrenocorticotrophic hormone and cortisol rhythms in human subjects (Licinio et al. 1997). In rats too the diurnal variation in leptin does not relate to the corticosteroid cycle (Ahima et al. 1996).

As well as a diurnal cycle of leptin secretion, an ultradian rhythm in the level of plasma leptin has been detected. In human subjects different pulse frequencies have been detected, depending on the frequency of sampling. At the most frequent sampling, there were thirty-two peaks over $24 \mathrm{~h}$ with a mean cycle duration of $32.8 \mathrm{~min}$ (Licinio et al. 1997), and it has been suggested that this frequency relates best to the frequency of fluctuation of catecholamine levels in plasma rather than to the intrinsic frequencies of secretion of insulin or corticosteroids (Himms-Hagen, 1999). It is possible that the sympathetic system exerts a tonic 
inhibition of leptin synthesis rather than merely switching off leptin production in response to an emergency; this tonic control may well be pulsatile as well.

\section{The sympathetic regulation of other secretions from white adipose tissue}

A detailed consideration of other secretions from adipose tissue is given in a companion review (Trayhurn \& Beattie, 2001). The sympathetic regulation of many adipose tissue secretions is less well documented than that for leptin. Lipoprotein lipase, which is secreted from adipose tissue and leads to the lipolysis of circulating triacylglycerol before entry into adipose tissue, is clearly down regulated by the sympathetics; levels and gene expression in adipose tissue are decreased by sympathomimetic amines (Deshaies et al. 1993), fasting (Picard et al. 2000), or cold exposure (Bertin et al. 1985). There is direct evidence for the sympathetic regulation of plasminogen activator inhibitor-1 and angiotensinogen in WAT. Plasminogen activator inhibitor-1 inhibits the activation of plasminogen to plasmin, and hence inhibits the breakdown of fibrin. Plasminogen activator inhibitor-1 levels in WAT are raised in obesity, and catecholamines are inhibitory in rodents (Gottschling-Zeller et al. 1999; Halleux et al. 1999). Adipose tissue is second only to the liver in the production of angiotensinogen (Jones et al. 1997). Fasting increases angiotensinogen gene expression in adipose tissue, while having no effect on its expression in the liver (Frederich et al. 1992). Angiotensinogen mRNA in WAT is also down regulated by $\beta$-adrenergic stimulation (Jones et al. 1997). Surprisingly, angiotensinogen mRNA levels vary in different animal models of obesity, angiotensinogen mRNA in WAT being increased in $o b / o b$ mice (Frederich et al. 1992) but reduced in fa/fa rats (Jones et al. 1997). In human subjects, angiotensinogen levels are raised in obesity (Faloia et al. 2000) and have been linked with the hypertension sometimes found. Among pro-inflammatory cytokines, interleukin- 6 is increased by $\beta$-adrenergic stimulation in human subjects and in isolated adipocytes (Mohamed-Ali et al. 2000). TNF- $\alpha$ is increased on adrenergic stimulation (Orban et al. 1999). TNF- $\alpha$ is interesting in that it is known to regulate other adipose tissue secretions such as leptin and plasminogen activator inhibitor-1 (Samad et al. 1999), so that there is a possibility of indirect TNF$\alpha$-mediated sympathetic regulation. TNF- $\alpha$ is also able to down regulate $\beta$-receptors and adrenergic function in adipocytes (Berkowitz et al. 1998), indicating the complexity of the modulation of sympathetic regulation in this tissue. The metallothionein gene has recently been shown to be expressed in adipose tissue. Metallothionein gene expression is not altered by fasting, but is increased by a $\beta 3$-agonist (Trayhurn et al. 2000). Recently, two new secretions from adipose tissue have been documented. Fasting-induced adipose tissue factor, a target for peroxisome proliferator-activated receptor $\alpha$, is increased on fasting (Kersten et al. 2000), while resistin, which increases with high-fat feeding and decreases insulin sensitivity, is decreased in fasting (Steppan et al. 2001). Although fasting is a useful means of perturbing the sympathetic system, it has other metabolic effects, such as reducing insulin secretion and increasing glucocorticoid secretion. Other factors are known to be secreted from adipose tissue, but are not at present known to be sympathetically regulated. Examples are retinol-binding protein (Montague et al. 1998) which is involved in the transport of retinoids, and adiponectin which is a collagen-like plasma protein that has an inhibitory effect on the proliferation of vascular smooth muscle cells and is the product of the adipose tissue-specific and most abundant gene transcript, apM1. Its plasma levels are decreased in obesity (Arita et al. 1999).

\section{Sympathetic control in obesity}

Obese rodents ( $f a / f a, o b / o b, d b / d b$ mutants) and human subjects have decreased responsiveness to sympathetic stimulation and have down regulated $\beta$-adrenoceptors in WAT (Muzzin et al. 1991; Collins et al. 1994, 1997, 1999; Breslow et al. 1997). This effect is manifested by both decreased fatty acid mobilisation and decreased responsiveness of the leptin system to sympathetic stimulation (fasting (Trayhurn et al. 1995b; Hardie et al. 1996), sympathomimetic amines or $\alpha$ MPT (Rayner et al. 1998)). The decreased $\beta 3$-receptor sensitivity may in turn be associated with the decreased leptin sensitivity or absence of leptin. Thus, in $o b / o b$ mice leptin treatment increases $\beta 3$ adrenoceptor expression (Breslow et al. 1997).

Obesity is sometimes associated with hypertension in human subjects (Rumantir et al. 1999) and in some rodent models of obesity (e.g. fa/fa rats (Carlson et al. 2000) but not $o b / o b$ mice). The hypertension often seen in obesity has been linked with increased sympathetic tone and with increased noradrenaline spillover from the kidneys and heart (Dunbar et al. 1997; Haynes et al. 1997). While sympathetic activity to, or responsiveness of, WAT itself may be decreased, it is possible that sympathetic activity to other organs may be increased to raise their metabolic rate as part of an attempted homeostatic regulation of the increased energy accretion, but may result also in an increase in blood pressure (Dunbar et al. 1997). This effect may link with the actions of leptin in increasing glucose and fat metabolism, which have been already mentioned.

\section{An overview of the role of the sympathetic system in the regulation of adipose tissue secretion}

The sympathetics (the system for 'fight or flight') inhibit a number of adipose tissue secretions. This action is best exemplified by leptin, the hormone of plenty that stimulates haematopoiesis, angiogenesis and reproductive function, and acts as a growth factor and as a metabolic regulator; functions that are necessary for long-term survival rather than short-term survival. The altered levels of many of these secretions in obesity may relate to the decreased sympathetic regulation as well as the increased fat mass, and they are likely to contribute to the increased morbidity and mortality of obesity. It is therefore important to understand the extent and importance of sympathetic actions.

\section{Acknowledgements}

I am grateful to the Scottish Executive Rural Affairs Department for the funding of this programme and for the 
support of my colleagues in the Molecular Physiology group at the Rowett Research Institute.

\section{References}

Ahima RS, Prabakaran D, Mantzoros C, Qu DO, Lowell B, Maratosflier E \& Flier JS (1996) Role of leptin in the neuroendocrine response to fasting. Nature 382, 250-252.

Arch JRS \& Wilson S (1996) $\beta 3$-Adrenoceptors and the regulation of metabolism in adipose tissues. Biochemical Society Transactions 24, 412-418.

Arita Y, Kihara S, Ouchi N, Takahashi M, Maeda K, Miyagawa J, Hotta K, Shimomura I, Nakamura T, Miyaoka K, Kuriyama H, Nishida M, Yamashita S, Okubo K, Matsubara K, Muraguchi M, Ohmoto Y, Funahashi T \& Matsuzawa Y (1999) Paradoxical decrease of an adipose-specific protein, adiponectin, in obesity. Biochemical and Biophysical Research Communications 257, 79-83.

Bartness TJ \& Bamshad M (1998) Innervation of mammalian white adipose tissue: implications for the regulation of total body fat. American Journal of Physiology 275, R1399-R1411.

Berkowitz DE, Brown D, Lee KM, Emala C, Palmer D, An Y \& Breslow M (1998) Endotoxin-induced alteration in the expression of leptin and beta(3)-adrenergic receptor in adipose tissue. American Journal of Physiology 274, E992-E997.

Bertin R, Triconnet M \& Portet R (1985) Effects of cold acclimation on the activity of lipoprotein lipase in adipose tissues of genetically obese Zucker rats. Comparative Biochemistry and Physiology 81B, 797-801.

Bing C, Pickavance L, Wang Q, Frankish H, Trayhurn P \& Williams G (1997) Role of hypothalamic neuropeptide Y neurons in the defective thermogenic response to acute cold exposure in fatty Zucker rats. Neuroscience 80, 277-284.

Boden G, Chen X, Mozzoli M \& Ryan I (1996) Effect of fasting on serum leptin in normal human subjects. Journal of Clinical Endocrinology and Metabolism 81, 3419-3423.

Boss O, Samec S, Dulloo A, Seydoux J, Muzzin P \& Giacobino JP (1997) Tissue-dependent upregulation of rat uncoupling protein2 expression in response to fasting or cold. FEBS Letters $\mathbf{4 1 2}$, 111-114.

Boss O, Samec S, Kuhne F, Bijlenga P, Assimacopoulos-Jeannet F, Seydoux J, Giacobino JP \& Muzzin P (1998) Uncoupling protein-3 expression in rodent skeletal muscle is modulated by food intake but not by changes in environmental temperature. Journal of Biological Chemistry 273, 5-8.

Breslow MJ, An Y \& Berkowitz DE (1997) Beta-3 adrenoceptor (beta-3AR) expression in leptin treated $\mathrm{Ob} / \mathrm{Ob}$ mice. Life Sciences 61, 59-64.

Campfield LA, Smith FJ, Guisez Y, Devos R \& Burn P (1995) Recombinant mouse OB protein: Evidence for a peripheral signal linking adiposity and central neural networks. Science 269, 546-549.

Cannon WB (1929) Bodily Changes in Pain, Hunger, Fear and Rage. New York and London: D. Appleton and Co.

Carlson SH, Shelton J, White CR \& Wyss JM (2000) Elevated sympathetic activity contributes to hypertension and salt sensitivity in diabetic obese Zucker rats. Hypertension 35, 403-408.

Cinti S (1999) The Adipose Organ. Milan: Editrice Kurtis s.r.l.

Cinti S (2001) The adipose organ: morphological perspectives of adipose tissues. Proceedings of the Nutrition Society 60, 319-328.

Collins S, Daniel KW, Petro AE \& Surwit RS (1997) Strainspecific response to beta(3)-adrenergic receptor agonist treatment of diet-induced obesity in mice. Endocrinology $\mathbf{1 3 8}$, 405-413.
Collins S, Daniel KW \& Rohlfs EM (1999) Depressed expression of adipocyte beta-adrenergic receptors is a common feature of congenital and diet-induced obesity in rodents. International Journal of Obesity 23, 669-677.

Collins S, Daniel KW, Rholfs EM, Ramkumar V, Taylor IL \& Gettys TW (1994) Impaired expression and functional activity of the $\beta 3$ - and $\beta 1$-adrenergic receptors in adipose tissue of congenitally obese (C57B1/6J ob/ob) mice. Molecular Endocrinology 8 , 518-527.

Collins S, Kuhn CM, Petro AE, Swick AG, Chrunyk BA \& Surwit RS (1996) Role of leptin in fat regulation. Nature 380, 677.

Deshaies Y, Géloën A, Paulin A, Marette A \& Bukowiecki LJ (1993) Tissue-specific alterations in lipoprotein lipase activity in the rat after chronic infusion of isoproterenol. Hormone and Metabolic Research 25, 13-16.

Dunbar JC, Hu YG \& Lu HQ (1997) Intracerebroventricular leptin increases lumbar and renal sympathetic nerve activity and blood pressure in normal rats. Diabetes 46, 2040-2043.

Emilsson V, Summers RJ, Hamilton S, Liu YL \& Cawthorne MA (1998) The effects of the beta(3)-adrenoceptor agonist BRL 35135 on UCP isoform mRNA expression. Biochemical and Biophysical Research Communications 252, 450-454.

Enocksson S, Shimizu M \& Lönnqvist F (1995) Demonstration of an in vivo functional $\beta 3$-adrenoceptor in man. Journal of Clinical Investigation 95, 2239-2245.

Faintrenie G \& Geloen A (1996) Alpha-1 adrenergic regulation of lactate production by white adipocytes. Journal of Pharmacology and Experimental Therapeutics 277, 235-238.

Faloia E, Giacchetti G \& Mantero F (2000) Obesity and hypertension. Journal of Endocrinological Investigation 23, 54-62.

Fleury C, Neverova M, Collins S, Raimbault S, Champigny O, Levimeyrueis C, Bouillaud F, Seldin MF, Surwit RS, Ricquier D \& Warden CH (1997) Uncoupling protein-2: A novel gene linked to obesity and hyperinsulinemia. Nature Genetics 15, 269-272.

Frederich RC, Kahn BB, Peach MJ \& Flier JS (1992) Tissuespecific nutritional regulation of angiotensinogen in adipose tissue. Hypertension 19, 339-344.

Garofalo MAR, Kettelhut IC, Roselino JES \& Migliorini RH (1996) Effect of acute cold exposure on norepinephrine turnover rates in rat adipose tissue. Journal of the Autonomic Nervous System 60, 206-208.

Giacobino JP (1996) Role of the b(3)-adrenoceptor in the control of leptin expression. Hormone and Metabolic Research 28, 633-637.

Gilgen A, Maickel RP, Nikoulina SE \& Brodie BB (1962) Essential role of catecholamines in the mobilisation of free fatty acids and glucose after exposure to cold. Life Sciences 1, 709-715.

Gomez-Ambrosi J, Fruhbeck G \& Martinez JA (1999) Leptin, but not a beta(3)-adrenergic agonist, upregulates muscle uncoupling protein-3 messenger RNA expression: short-term thermogenic interactions. Cellular and Molecular Life Sciences 55, 992-997.

Gottschling-Zeller H, Birel M \& Hauner H (1999) Effect of $\beta$ adrenoceptor agonists on plasminogen activator inhibitor-1 secretion from human adipocytes in suspension culture. International Journal of Obesity 23, Suppl. 5, S25.

Halleux CM, Declerck PJ, Tran SL, Detry R \& Brichard SM (1999) Hormonal control of plasminogen activator inhibitor-1 gene expression and production in human adipose tissue: stimulation by glucocorticoids and inhibition by catecholamines. Journal of Clinical Endocrinology and Metabolism 84, 4097-4105.

Haque MS, Minokoshi Y, Hamai M, Iwai M, Horiuchi M \& Shimazu T (1999) Role of the sympathetic nervous system and insulin in enhancing glucose uptake in peripheral tissues after intrahypothalamic injection of leptin in rats. Diabetes $\mathbf{4 8}$, 1706-1712.

Hardie LJ, Rayner DV, Holmes S \& Trayhurn P (1996) Circulating leptin levels are modulated by fasting, cold exposure and insulin 
administration in lean but not Zucker $(f a / f a)$ rats as measured by ELISA. Biochemical and Biophysical Research Communications 223, 660-665.

Haynes WG, Morgan DA, Walsh SA, Mark AL \& Sivitz WI (1997) Receptor-mediated regional sympathetic nerve activation by leptin. Journal of Clinical Investigation 100, 270-278.

Himms-Hagen J (1999) Physiological roles of the leptin endocrine system: Differences between mice and humans. Critical Reviews in Clinical and Laboratory Science 36, 575-655.

Hjemdahl P \& Linde B (1983) Influence of circulating NE and Epi on adipose tissue vascular resistance and lipolysis in humans. American Journal of Physiology 245, H447-H452.

Hoffstedt J, Arner P, Hellers G \& Lönnqvist F (1997) Variation in adrenergic regulation of lipolysis between omental and subcutaneous adipocytes from obese and non-obese men. Journal of Lipid Research 38, 795-804.

Jones BH, Standridge MK, Taylor JW \& Moustaid N (1997) Angiotensinogen gene expression in adipose tissue: analysis of obese models and hormonal and nutritional control. American Journal of Physiology 273, R236-R242.

Kamora S, Burcelin R, Halaas JL, Friedman JM \& Charron MJ (1997) Acute stimulation of glucose metabolism in mice by leptin treatment. Nature 389, 374-377.

Kersten S, Mandarino LJ, Tan NS, Escher P, Metzger D, Chambon P, Gonzalez FJ, Desvergne B \& Wahli W (2000) Characterization of the fasting-induced adipose factor FIAF, a novel peroxisome proliferator-activated receptor target gene. Journal of Biological Chemistry 275, 28488-28493.

Kolaczynski JW, Ohannesian JP, Considine RV, Marco CC \& Caro JF (1996) Response of leptin to short-term and prolonged overfeeding in humans. Journal of Clinical Endocrinology and Metabolism 81, 4162-4165.

Kopin IJ (1989) Plasma levels of catecholamines and dopamine- $\beta$ hydroxylase. In Handbook of Experimental Pharmacology, Catecholamines II, pp. 211-275 [U Trendelenberg and N Weiner, editors]. Berlin: Springer Verlag.

Lafontan M \& Berlan M (1993) Fat cell adrenergic receptors and the control of white and brown fat cell function. Journal of Lipid Research 34, 1057-1091.

Lansberg L \& Young JB (1978) Fasting, feeding and regulation of the sympathetic nervous system. New England Journal of Medicine 298, 1295-1301.

Licinio J, Mantzoros C, Negrao AB, Cizza G, Wong ML, Bongiorno PB, Chrousos GP, Karp B, Allen C, Flier JS \& Gold PW (1997) Human leptin levels are pulsatile and inversely related to pituitary-adrenal function. Nature Medicine 3, 575-579.

Liu Q, Bai C, Chen F, Wang RP, Macdonald T, Gu MC, Zhang Q, Morsy MA \& Caskey CT (1998) Uncoupling protein-3: a muscle-specific gene upregulated by leptin in ob/ob mice. Gene 207, 1-7.

Mercer JG, Moar KM \& Hoggard N (1998) Localization of leptin receptor $(\mathrm{Ob}-\mathrm{R})$ messenger ribonucleic acid in the rodent hindbrain. Endocrinology 139, 29-34.

Migliorini RH, Garofalo MAR \& Kettelhut IC (1997) Increased sympathetic activity in rat white adipose tissue during prolonged fasting. American Journal of Physiology 272, R656-R661.

Minokoshi Y, Haque MS \& Shimazu T (1999) Microinjection of leptin into the ventromedial hypothalamus increases glucose uptake in peripheral tissues in rats. Diabetes $\mathbf{4 8}$, 287-291.

Mohamed-Ali V, Bulmer K, Clarke D, Goodrick S, Coppack SW \& Pinkney JH (2000) beta-Adrenergic regulation of proinflammatory cytokines in humans. International Journal of Obesity 24, S154-S155.
Mohamed-Ali V, Pinkney JH \& Coppack SW (1998) Adipose tissue as an endocrine and paracrine organ. International Journal of Obesity 22, 1145-1158.

Moinat M, Deng CJ, Muzzin P, Assimacopoulos-Jeannet F, Seydoux J, Dulloo AG \& Giacobino JP (1995) Modulation of obese gene expression in rat brown and white adipose tissues. FEBS Letters 373, 131-134.

Montague CT, Prins JB \& Sanders I (1998) Depot-related gene expression in human subcutaneous and omental adipocytes. Diabetes 47, 1384-1391.

Muzzin P, Revelli J-P, Kuhne F, Gocayne JD, McCombie WR, Venter JC, Giacobino J-P \& Fraser CM (1991) An adipose tissue-specific $\beta$-adrenergic receptor. Molecular cloning and down-regulation in obesity. Journal of Biological Chemistry 266, 24053-24058.

Niijima A (1998) Afferent signals from leptin sensors in the white adipose tissue of the epididymis, and their reflex effect in the rat. Journal of the Autonomic Nervous System 73, 19-25.

Orban Z, Remaley AT, Sampson M, Trajanoski Z \& Chrousos GP (1999) The differential effect of food intake and beta-adrenergic stimulation on adipose-derived hormones and cytokines in man. Journal of Clinical Endocrinology and Metabolism 84, 2126-2133.

Pellymounter MA, Cullen MJ, Baker MB, Hecht R, Winter D, Boone T \& Collins F (1995) Effects of the obese gene product on body weight regulation in $o b / o b$ mice. Science 269, 540-543.

Picard F, Richard D, Timofeeva E \& Deshaies Y (2000) Abnormal insulin and beta-adrenergic modulation of lipoprotein lipase during refeeding after prolonged fasting in the Zucker rat. Diabetologia 43, 866-874.

Rayner DV, Simon E, Duncan JS \& Trayhurn P (1998) Hyperleptinaemia in mice induced by administration of the tyrosine hydroxylase inhibitor $\alpha$-methyl-p-tyrosine. FEBS Letters 429, 395-398.

Rebuffé-Scrive M (1991) Neuroregulation of adipose tissue: Molecular and hormonal mechanisms. International Journal of Obesity 15, 83-86.

Richelsen B, Pedersen SB, Møller-Pedersen T \& Bak JF (1991) Regional differences in triglyceride breakdown in human adipose tissue: Effects of catecholamines, insulin and prostoglandin $\mathrm{E}_{2}$. Metabolism 40, 990-996.

Ricquier D \& Bouillaud F (2000) The uncoupling protein homologues: UCP1, UCP2, UCP3, StUCP and AtUCP. Biochemical Journal 345, 161-179.

Rumantir MS, Vaz M, Jennings GL, Collier G, Kaye DM, Seals DR, Wiesner GH, BrunnerLaRocca HP \& Esler MD (1999) Neural mechanisms in human obesity-related hypertension. Journal of Hypertension 17, 1125-1133.

Samad F, Uysal KT, Wiesbrock SM, Pandey M, Hotamisligil GS \& Loskutoff DJ (1999) Tumor necrosis factor alpha is a key component in the obesity-linked elevation of plasminogen activator inhibitor 1. Proceedings of the National Academy of Sciences USA 96, 6902-6907.

Satoh N, Ogawa Y, Katsuura G, Numata Y, Tsuji T, Hayase M, Ebihara K, Masuzaki H, Hosoda K, Yoshimasa Y \& Nakao K (1999) Sympathetic activation of leptin via the ventromedial hypothalamus - Leptin-induced increase in catecholamine secretion. Diabetes 48, 1787-1793.

Savontaus E, Rouru J, Boss O, Huupponen R \& Koulu M (1998) Differential regulation of uncoupling proteins by chronic treatments with beta(3)-adrenergic agonist BRL 35135 and metformin in obese fa/fa Zucker rats. Biochemical and Biophysical Research Communications 246, 899-904.

Scarpace PJ \& Matheny M (1998) Leptin induction of UCP1 gene expression is dependent on sympathetic innervation. American Journal of Physiology 275, E259-E264. 
Scarpace PJ, Matheny M, Pollock BH \& Tumer N (1997) Leptin increases uncoupling protein expression and energy expenditure. American Journal of Physiology 273, E226-E230.

Scarpace PJ, Nicolson M \& Matheny M (1998) UCP2, UCP3 and leptin gene expression: modulation by food restriction and leptin. Journal of Endocrinology 159, 349-357.

Schoeller DA, Cella LK, Sinha MK \& Caro JF (1997) Entrainment of the diurnal rhythm of plasma leptin to meal timing. Journal of Clinical Investigation 100, 1882-1887.

Sennitt MV, Kaumann AJ, Molenaar P, Beeley LJ, Young PW, Kelly J, Chapman H, Henson SM, Berge JM, Dean DK, Kotecha NR, Morgan HK, Rami HK, Ward RW, Thompson M, Wilson S, Smith SA, Cawthorne MA, Stock MJ \& Arch JR (1998) The contribution of classical (beta 1/2-) and atypical beta-adrenoceptors to the stimulation of human white adipocyte lipolysis and right atrial appendage contraction by novel beta3-adrenoceptor agonists of differing selectivities. Journal of Pharmacology and Experimental Therapeutics 285, 1084-1095.

Sinha MK, Ohannesian JP, Heiman ML, Kriauciunas A, Stephens TW, Magosin S, Marco C \& Caro JF (1996) Nocturnal rise of leptin in lean, obese, and non-insulin-dependent diabetes mellitus subjects. Journal of Clinical Investigation 97, 1344-1347.

Sivitz WI, Fink BD, Morgan DA, Fox JM, Donohoue PA \& Haynes WG (1999) Sympathetic inhibition, leptin, and uncoupling protein subtype expression in normal fasting rats. American Journal of Physiology 277, E668-E677.

Steppan CM, Bailey ST, Bhat S, Brown EJ, Banerjee RR, Wright CM, Patel HR, Ahima RS \& Lazar MA (2001) The hormone resistin links obesity to diabetes. Nature 409, 307-312.

Tate KM, Briend-Sutren M-M, Emorine LJ, Delavier-Klutchko C, Marullo S \& Strosberg AD (1991) Expression of three human $\beta$ adrenergic-receptor subtypes in transfected chinese hamster ovary cells. European Journal of Biochemistry 196, 357-361.

Tavernier G, Barbe P, Galitzky J, Berlan M, Caput D, Lafontan M \& Langin D (1996) Expression of $\beta 3$-adrenoceptors with low lipolytic action in human subcutaneous white adipose tissue. Journal of Lipid Research 37, 87-97.

Thomas SA \& Palmiter RD (1997) Thermoregulatory and metabolic phenotypes of mice lacking noradrenaline and adrenaline. Nature 387, 94-97.

Trayhurn P \& Beattie JH (2001) Physiological role of adipose tissue: white adipose tissue as an endocrine and secretory organ. Proceedings of the Nutrition Society 60, 329-339.

Trayhurn P, Duncan JS \& Rayner DV (1995a) Acute cold-induced suppression of $o b$ (obese) gene expression in white adipose tissue of mice: Mediation by the sympathetic system. Biochemical Journal 311, 729-733.

Trayhurn P, Duncan JS, Rayner DV \& Hardie LJ (1996) Rapid inhibition of $o b$ gene expression and circulating leptin levels in lean mice by the beta 3 -adrenoceptor agonists BRL 35135A and ZD2079. Biochemical and Biophysical Research Communications 228, 605-610.

Trayhurn P, Duncan JS, Wood AM \& Beattie JH (2000) Metallothionein gene expression and secretion by white adipose tissue. American Journal of Physiology 279, R2329-R2335.

Trayhurn P, Thomas MEA, Duncan JS \& Rayner DV (1995b) Effects of fasting and refeeding on $o b$ gene expression in white adipose tissue of lean and obese (ob/ob) mice. FEBS Letters $\mathbf{3 6 8}$, 488-490.

Young JB \& Lansberg L (1977) Suppression of sympathetic nervous system during fasting. Science 196, 1473-1475.

Young JB, Rosa RM \& Landsberg L (1984) Dissociation of sympathetic nervous system and adrenal medullary responses. American Journal of Physiology 247, E35-E40.

Zhang Y, Proenca R, Maffei M, Barone M, Leopold L \& Friedman JM (1994) Positional cloning of the mouse obese gene and its human homologue. Nature 372, 425-432.

Zhou YT, Shimabukuro M, Koyama K, Lee Y, Wang MY, Trieu F, Newgard CB \& Unger RH (1997) Induction by leptin of uncoupling protein-2 and enzymes of fatty acid oxidation. Proceedings of the National Academy of Sciences USA 94, 6386-6390. 